\title{
The Glucose Level of Blood Collected from Rabbits (Belgian Giant Breed) and Hares (Lepus europaeus Pallas)
}

\author{
Gabriela TĂRNĂUCEANU (FRUNZĂ)* \\ University of Agricultural Sciences and Veterinary Medicine Iasi, Romania \\ *Corresponding author, e-mail: tarnauceanu.gabriela@yahoo.com \\ Bulletin UASVM Animal Science and Biotechnologies 72(1) / 2015 \\ Print ISSN 1843-5262; Electronic ISSN 1843-536X \\ DOI:10.15835/buasvmcn-asb:10391
}

\begin{abstract}
This paper is part of a broader study aimed at comparative characterization of the rabbits (Belgian Giant breed) and hares (Lepus europaeus Pallas) of meat and physiological status. For hares very few data are available and were observed significant differences at the level of females and males in two studies carried out in Italy (Paci et al., 2007, 2006) in which were evaluated implications of the stress, of habitat and density on metabolic profile. The purpose of this study was to establish the energetic profile of rabbits (Belgian Giant breed) and hares (Lepus europaeus Pallas) by determining the glucose level of blood. The biological material consisted of 85 individuals: 49 hares and 36 rabbits. The energetic profile has been determined using ACCENT 200 automatic device. To test the statistical significance of differences of obtained results, we used ANOVA Single Factor algorithm. Mean values of the glucose level have varied for rabbits $(90.8 \mathrm{mg} / \mathrm{dL}$ for females and $97.3 / \mathrm{dL}$ for males) and hares $(132.3 \mathrm{mg} / \mathrm{dL}$ for females and $124.9 \mathrm{mg} / \mathrm{dL}$ for males). After applying statistical analysis were revealed insignificant differences between sexes $(\mathrm{p}<0.05)$ at the level of the same species. The variation of glucose level for hares and rabbits is mainly due to the stress factor, in hares having a more pronounced character since they are wild animals.
\end{abstract}

Keywords: blood, energetic profile, hare, rabbit

\section{INTRODUCTION}

Carbohydrate metabolism disturbances addressed starting from the glucose level. The glucose is the major energy resource immediately usable by the body. In the systemic circulation was found only glucose as the only immediately source of energy for the brain (Pârvu, 1992)). The symptoms of hypoglycemia occur from the nervous system activity since it is highly dependent on blood glucose (Burnet et al., 2006; Paci et al., 2006, 2007; Pârvu, 1992).

\section{AIMS AND OBJECTIVES}

The aim of this study was to establish the physiological status of rabbits (Belgian Giant breed) and hares (Lepus europaeus Pallas) by determining the energetic profile of blood and also, the comparative observation of stress response to specific conditions of life of the two species by glucose level (Tărnăuceanu (Frunză) et al., 2014a,b).

\section{MATERIALS AND METHODS}

The biological material consisted of 85 individuals: 49 hares (24 males and 25 females) and 36 rabbits ( 5 males and 31 females). Hares were collected (during hunting seasons) from Iasi County hunting funds. Both species were studied at reproductive maturity age (11-12 months). The rabbits (Belgian Giant breed) had an average body weight of $11.5 \mathrm{~kg}$ and the hares an average weight of $5.6 \mathrm{~kg}$. Blood collection was performed on live hares, caught in the net, fed and accommodated in the dark for not being stressed. For rabbits, blood sampling was performed in the same way excepting the darkness. Blood sampling for energetic profile was collected in vacuntainers without anticoagulant. In hares, blood was collected from the auricular and ulnar veins and at rabbits from auricular veins. The energetic profile was determined using ACCENT 200 automatic device. The principle is based on changing the wavelength known through a sample and measuring the 
Tab. 1. The energetic profile for rabbits and hares -glucose $(\mathrm{mg} / \mathrm{dL})$

\begin{tabular}{lccccc}
\hline The energetic profile -glucose & $\overline{\boldsymbol{X}} \pm \boldsymbol{S} \overline{\boldsymbol{x}}$ & $\mathrm{S}^{2}$ & $\mathrm{~V} \%$ & Min. & Max. \\
\hline Females Belgian Giant breed & $90.78 \pm 7.77$ & 38.36 & 4.69 & 24.00 & 82.00 \\
\hline Males Belgian Giant breed & $87.30 \pm 2.52$ & 5.66 & 9.00 & 74.00 & 82.00 \\
\hline Females Lepus europaeus & $132.30 \pm 58.58$ & 31.39 & 81.00 & 29.10 & 526.10 \\
\hline Males Lepus europaeus & $124.87 \pm 84.57$ & 29.90 & 64.87 & 51.29 & 41.10 \\
\hline
\end{tabular}

Tab. 2. Statistical significance of differences in the energetic profile of hares and rabbits, by gender

\begin{tabular}{lll}
\hline \multicolumn{2}{c}{ The energetic profile } & The statistical significance of differences \\
\hline \multirow{2}{*}{ Glucose } & Lepus europaeus Pallas females/males & $\hat{\mathrm{F}}=0.160 ; \mathrm{F}_{5 \%}(1 ; 15)=4.543 ; \hat{\mathrm{F}}<\mathrm{F}_{1 \%=} \mathrm{n} . \mathrm{s}$. \\
\cline { 2 - 3 } & Belgian Giant breed females/males & $\hat{\mathrm{F}}=1.349 ; \mathrm{F}_{5 \%}(1 ; 10)=4.964 ; \hat{\mathrm{F}}<\mathrm{F}_{5 \%}=$ n.s. \\
\hline
\end{tabular}

amount of light energy that is transmitted. For statistical significance of differences of obtained results, we used ANOVA Single Factor algorithm. The glucose level was determined using ACCENT 200 automatic device. The obtained results were statistically interpreted.

\section{RESULTS AND DISCUSSION}

The largest quantity of glucose was obtained for female hares $(132.3 \mathrm{ml} / \mathrm{dL})$ followed by the value for hare males $(124.87 \mathrm{ml} / \mathrm{dL})$. The results were similar to those obtained by Paci $(123 \mathrm{mg} / \mathrm{dL}$ for females and $126 \mathrm{mg} / \mathrm{dL}$ for males). For rabbits (Belgian Giant breed), the lowest glucose value has been obtained for males $(87.3 \mathrm{mg} / \mathrm{dL})$, and for females the average values was $90.8 \mathrm{mg} / \mathrm{dL}$ (Tab. 1).

The coefficient of variation for glucose level, for hares, exceeded the threshold of $20 \%$, which exemplifies a inhomogeneous population. For rabbits coefficient of variation did not exceed the $10 \%$ expressing a very homogeneous population (Tab. 1). After applying statistical analysis were revealed insignificant differences between sexes $(\mathrm{p}<0.05)$ at the level of the same species (Tab. 2).

In several studies, it is noted insignificant differences between genders for rabbits (Burnet et al., 2006). For hares were observed significant differences at the level of females and males in two studies conducted in Italy (Paci et al., 2007; 2006) in which implications of the stress, of the habitat and of the density, on the metabolic profile were evaluated. Increase in blood glucose (the hyperglycemia) above the normal values can be caused either by decreasing of glycogenesis or by the increase of glycogenolysis, both aspects being determined by the endocrine, hepatic or nervous factors (stress being the main factor which influence the level of glucose in the blood).

\section{CONCLUSION}

From made measurements, it was observed higher average value of blood glucose of hares than for rabbits. Mean values have varied for hares $(132.3 \mathrm{mg} / \mathrm{dL}$ for females and $124.9 \mathrm{mg} / \mathrm{dL}$ for males) and rabbits $(90.8 \mathrm{mg} / \mathrm{dL}$ for females and 97.3 / $\mathrm{dL}$ for males), that is mainly due to the stress factor, having a more pronounced character since they are wild animals.

\section{REFERENCES}

1. Paci G, Bagliacca M, Lavazza A (2006). Stress evaluation in hares (Lepus europaeus Pallas) captured for translocation, Italian J. of Animal Science, 5: 175-181.

2. Paci G, Lavazza A, Ferretti M, Bagliacca M (2007). Relationship between habitat, densities and metabolic profile in brown hares (Lepus europaeus Pallas), Italian J. Animal Science, 6: 241-255.

3. Burnett N, Mathura K, Metivier KS, Holder R, Brown G., Campbell $M$ (2006). An investigation into hematological and serum chemistry parameters of rabbits in Trinidad, World Rabbit Science, 14: 175-187.

4. Pârvu Gh (1992). Metabolic nutritional surveillance of animal, Ed. Ceres, Bucharest.

5. Tărnăuceanu (Frunză) G, Pop C, Boișteanu PC (2014a). The Assessment of Physiological Status of the Rabbits (Belgian Giant Breed) and Hares (Lepus europaeus Pallas) by Comparative Characterization of Haematological Profile. Scientific papers, Animal Husbandry Series, 61: 55-60.

6. Tărnăuceanu (Frunză) G, Pop C, Boişteanu PC (2014b). An investigation into Biochemical Profile of Blood Harvested from Rabbits (Belgian Giant breed) and Hares (Lepus europaeus Pallas). Scientific papers, Animal Husbandry Series, 61: 65-69. 